\title{
DETECTION OF A POSSIBLE CHANGE POINT IN ATMOSPHERIC VARIABILITY IN THE NORTH ATLANTIC AND ITS EFFECT ON SCANDINAVIAN GLACIER MASS BALANCE
}

\author{
ROWAN FEALY* and JOHN SWEENEY \\ ICARUS, Department Of Geography, NUI Maynooth, Co Kildare, Ireland \\ Received 1 January 2004 \\ Revised 16 May 2005 \\ Accepted 6 June 2005
}

\begin{abstract}
Climate change, resulting from an increase in global temperatures, is likely to have a large impact on glaciers and glacier meltwater during the course of the present century resulting in significant contributions to sea level rise. Globally, glaciers are in retreat, partly as a response to the return to warmer conditions after the last neoglacial period during the Little Ice Age but also because of the almost continuous increases evident in global temperature since then. In contrast, Scandinavian glaciers, particularly maritime glaciers, were maintaining equilibrium or advancing over the closing decades of the last century possibly resulting from an increased moisture flux over the North Atlantic. While the more continental glaciers were still declining, the rate of decline diminished during the late 1980s. This coincides with an accelerated rate of increase evident on the maritime glaciers in southwestern Norway. A change point in atmospheric variability in the North Atlantic is identified as having occurred during this period. This change point is associated with an intensification of westerlies over Europe, particularly since the late 1980s, which significantly contributes to increases in temperature and precipitation over northern Europe while suppressing the penetration of warm, moist air into more southern European locations. Regional variations in temperature and precipitation from selected Scandinavian stations are also found to be consistent with the changes in the large-scale modes of atmospheric variability in the North Atlantic. Copyright (C) 2005 Royal Meteorological Society.
\end{abstract}

KEY WORDS: Scandinavia; glacier mass balance; circulation changes; CUSUMs analysis; Pettitt analysis; change point

\section{INTRODUCTION}

A number of studies have identified a change point in climate as having occurred during the early 1970s (Hoppe and Kiely, 1999; Kiely, 1999) resulting in increases in precipitation in Ireland (Kiely, 1999) and Scotland (Smith, 1995), a change in the meteorological controls of Glacier de Sarennes during the ablation season (Vincent and Vallon, 1997), increasing precipitation intensity in Italy (Brunetti et al., 2001), increasing temperature at $300 \mathrm{hPa}$ in the lower and middle latitudes (Weber, 1997) and increasing $700 \mathrm{mb}$ heights over western Canada (McCabe and Fountain, 1995). This period also corresponds with a shift in the seasonal zonal frequency over Europe as outlined by Bardossy and Caspary (1990). They indicate that while the overall annual frequencies of zonal circulation remained constant, the seasonal frequencies were changing from about 1973, with increases apparent in December and January and decreases apparent in April and May. These changes were associated with relatively warmer and more humid winters in central Europe. The beginning of the 1970s also saw substantial increases in the decadal mean residence times of Grosswetterlagen types W (west) and CW (clustered west) over northwestern Europe (Werner et al., 2000). Werner et al. (2000) applied a similar analysis to the Lamb circulation types $16(\mathrm{~W})$ and $26(\mathrm{CW})$ and found similar results. An

* Correspondence to: Rowan Fealy, ICARUS, Department of Geography, NUI Maynooth, Co. Kildare, Ireland;

e-mail: rowan.fealy@nuim.ie 
outlier test of the decadal behaviour of the climate state signal identified the decade 1981-1990 as the onset of climate change in the North Atlantic area with a trend commencing in the early 1970s (Werner et al., 2000). This increase in zonal circulation also corresponds to a shift in the North Atlantic Oscillation (NAO) from being predominantly negative to being positive, a phase the NAO has largely persisted in since the 1970s.

Globally, there is evidence to suggest that glacier mass balance variability has been increasing, especially since the 1980s, which is likely attributable to climatic variability (Dyurgerov and Meier, 1999; Dyurgerov, 2002). Between 1982 and 1995, Storglaciären in Sweden recorded eight of its thirteen highest values of winter accumulation, while six of its summertime ablation values were among the lowest recorded, indicating an increase in the frequency of extremes (Pohjola and Rodgers, 1997b). These findings are consistent with those of Hurrell (1995) who suggests that the moisture flux over the North Atlantic has increased since the 1980s. In an analysis of the sensitivity of mountain and subpolar glaciers to climate warming between 1961 and 1976, Dyurgerov (2003) estimated that the glacier melt contribution to sea level rise was $0.15 \mathrm{~mm} / \mathrm{yr}$ or $10 \%$ of total sea level rise. However, this contribution increased to $0.41 \mathrm{~mm} / \mathrm{yr}$ or $27 \%$ of total sea level rise between 1988 and 1998 suggesting that glacier sensitivity to climate warming maybe accelerating.

The work described in this paper sets out to examine the effects of a possible change point in the largescale atmospheric circulation over the North Atlantic, identified as occurring in the late 1980s, on glacier mass balance in Scandinavia. While glacier mass balance in Scandinavia was increasing over the 1970-2000 period, particularly on the more maritime regime glaciers in southwestern Norway, the late 1980s marks a point at which the rate of increase is seen to accelerate. A number of simple techniques are employed on the data to identify the possible occurrence of change points in the large-scale atmospheric circulation data, described in Section 2, represented by the NAO and the East Atlantic-Jet Pattern (EA-JP).

In Section 3, the relationship between the atmospheric indices and glacier mass balance in Scandinavia is examined. These indices are further examined in Section 4 to determine if any changes that may have occurred in the atmospheric variability of the North Atlantic are reflected in the Scandinavian glacier mass balance series. The effects of significant change points will also be examined on the relationship between atmospheric variability and mass balance. Section 5 will assess changes in precipitation and temperature, two key meteorological parameters that affect glacier mass balance, associated with changes in the large-scale atmospheric variability in order to explain regional differences. The paper concludes with a discussion of the larger context of the findings.

\section{DATA AND VARIABLES}

The NAO is the leading mode of climate variability in the North Atlantic and accounts for up to $37 \%$ of the variability of the winter $500 \mathrm{hPa}$ heights in this region (Marshall et al., 2001). The NAO is characterised by a meridional or north-south pressure gradient between the semi-permanent low pressure centred over Iceland (Icelandic Low) and the semi-permanent high pressure centred over the Azores (Azores High). It is instrumental in the large-scale transfer and redistribution of atmospheric mass between the equator and the North Pole and is associated with changes in westerly airflow over the North Atlantic onto Europe (Hurrell, 1995). Positive phases of the NAO result in a change in storminess and storm track location (Rogers, 1990; Hurrell, 1995) which in turn produce changes in synoptic scale eddy transfer of warm, moist air between the equator and pole (Hurrell, 1995). It is most pronounced during the boreal winter months of December to March, but is present throughout the whole year (Marshall and Kushnir, 1997; Hurrell and Dickson, 2001). The NAO is also linked to the leading annular mode of climate variability in the Northern Hemisphere, the Arctic Oscillation (AO). Fluctuations in the NAO have also been found to co-vary with fluctuations in temperature and precipitation, two key variables that affect glacier mass balance.

The EA-JP is similarly characterised by a low pressure centre, located over the eastern North Atlantic and Scandinavia, and a high pressure centre, located over Northern Africa and the Mediterranean Sea. It is one of the dominant modes of variability in the North Atlantic between the months of April to August. A positive phase of the EA-JP also reflects an intensification of westerlies onto Europe during these months. 


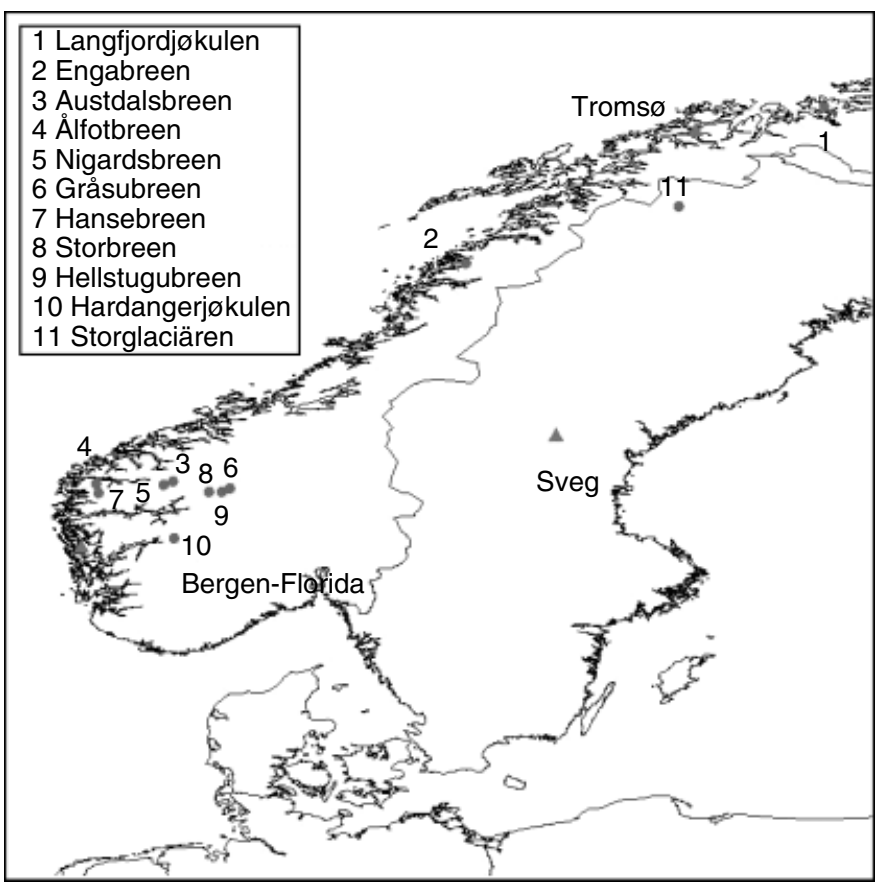

Figure 1. Location of glaciers $(\bullet)$ and climate stations $(\boldsymbol{\Delta})$

Mass balance data for both the accumulation and ablation seasons were obtained for a number of glaciers in Norway covering the period 1962-2000 (Figure 1). In addition, Storglaciären in Sweden was included because of its extended data record, which covers the period 1945-1999. As the mass balance of a glacier reflects the climatic setting and site-specific glacier morphology, it is therefore an important link between climatic inputs and glacier behaviour (Benn and Evans, 1998).

Monthly precipitation and temperature data was also obtained for the period 1900-2000 for three stations in Scandinavia (extracted from the Nordklim data set 1.0) (Tuomenvirta et al., 2001). Bergen $\left(60^{\circ} 23^{\prime} \mathrm{N} 5^{\circ} 20^{\prime} \mathrm{E}\right)$, located in southwestern Norway and illustrative of maritime conditions, Troms $\varnothing\left(69^{\circ} 39^{\prime} \mathrm{N} 18^{\circ} 56^{\prime} \mathrm{E}\right)$, located in northern Norway and Sveg $\left(62^{\circ} 1^{\prime} \mathrm{N} 15^{\circ} 37^{\prime} \mathrm{E}\right)$ located in Sweden and representative of a more continental regime climate were also included for analysis (Figure 1).

\section{RELATIONSHIP BETWEEN ATMOSPHERIC MODES OF VARIABILITY AND SCANDINAVIAN GLACIER MASS BALANCE}

Glaciers have for long been recognised as sensitive to climatic variability (Oerlemans, 2005), and a number of previous studies have linked atmospheric modes of variability and, in particular, the NAO to European glacier mass balance (Pohjola and Rodgers, 1997a,b; Washington et al., 2000; Nesje and Dahl, 2000; Nesje et al., 2000; Six et al., 2001). Table I displays the relationship between the NAO, seasonally averaged over the months of December to March, winter glacier mass balance $(B \mathrm{w})$ and annual glacier mass balance $(B \mathrm{n})$. Also shown is the relationship between the EA-JP and summer glacier mass balance $(B \mathrm{~s})$. The NAO is shown to be positively correlated with both winter and net glacier mass balance. However, the relationship tends to weaken or breakdown completely as a consequence of increasing latitude and continentality (Figure 2). This weakening in the relationship appears to relate to the extent of effective advection of heat by westerlies (Chen and Hellström, 1999). The positive correlation between the EA-JP and Bs reflects the influence of oceanic air mass types during the summer months which would act to suppress the warmer continental air mass types, thereby reducing ablation in years with positive EA-JP index values. 
Table I. Correlations between winter balance $(B \mathrm{w})$, net balance $(B \mathrm{n})$ and summer balance $(B \mathrm{~s})$ for a selected number of Scandinavian glaciers and the NAO (seasonal average between December and March) and the EA-JP

\begin{tabular}{lccc}
\hline Glacier & $B \mathrm{w} / \mathrm{NAO}$ & $B \mathrm{n} / \mathrm{NAO}$ & $B \mathrm{~s} / \mathrm{EA}-\mathrm{JP}$ \\
\hline Ålfotbreen & $0.78^{\mathrm{b}}$ & $0.71^{\mathrm{b}}$ & \\
Nigardsbreen & $0.71^{\mathrm{b}}$ & $0.60^{\mathrm{b}}$ & $0.45^{\mathrm{b}}$ \\
Hardangerjøkulen $_{\text {Storbreen }}$ & $0.74^{\mathrm{b}}$ & $0.70^{\mathrm{b}}$ & $0.37^{\mathrm{b}}$ \\
Hellstugubreen & $0.62^{\mathrm{b}}$ & $0.51^{\mathrm{b}}$ & $0.30^{\mathrm{b}}$ \\
Gråsubreen $_{\text {Engabreen }}$ & $0.65^{\mathrm{b}}$ & $0.47^{\mathrm{b}}$ & $0.46^{\mathrm{b}}$ \\
Storglaciären $^{\mathrm{d}}$ & $0.61^{\mathrm{b}}$ & $0.34^{\mathrm{b}}$ & $0.45^{\mathrm{b}, \mathrm{c}}$ \\
\hline
\end{tabular}

b (a) Correlation is significant at the $0.01(0.05)$ level (two-tailed).

${ }^{\mathrm{c}}$ Gråsubreen was the only glacier in which the summer balance was significantly correlated with the NAO seasonally averaged over June-August.

${ }^{\mathrm{d}}$ Storglaciären included because of the record length.

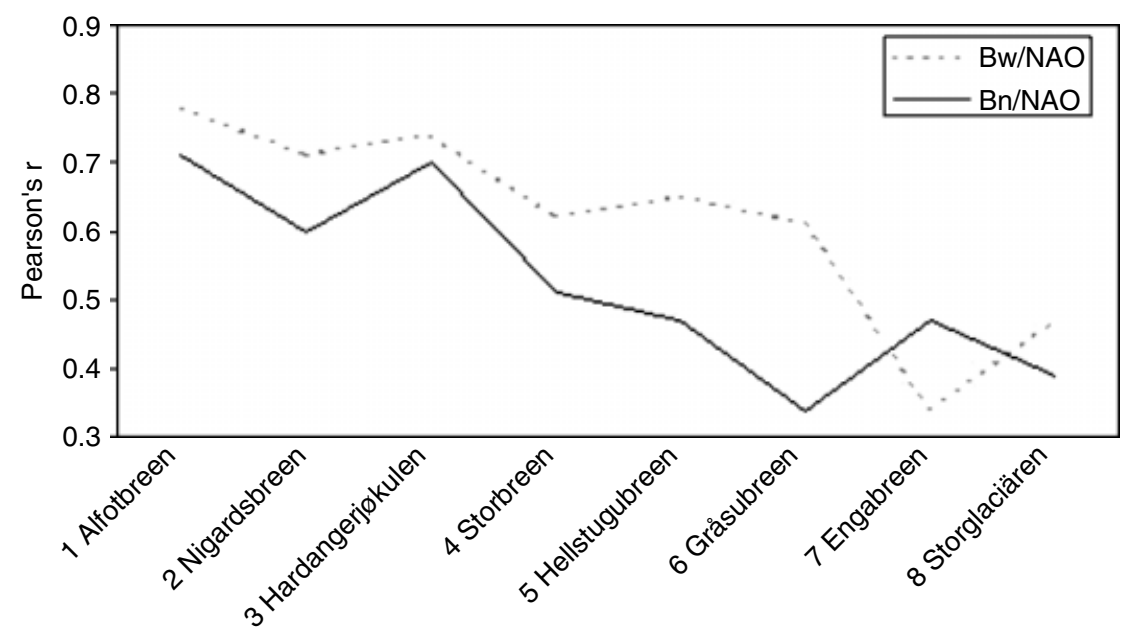

Figure 2. Correlation between glacier mass balance and the NAO indicating a decreasing relationship with increasing continentality of glacier location (1-6 southern Norway; 7-8 northern Scandinavia)

As a consequence of the largely positive phase of the NAO since the 1970s (Figure 3) resulting in the enhanced advection of warm, moist air in to Northern Europe during the winter months, a number of Scandinavian glaciers, particularly maritime glaciers, have demonstrated a tendency towards positive net balances over the closing three decades of the last century. This tendency towards more positive net balances is largely in phase with the NAO and in contrast to the mass glacier recession evident in nearly all glaciated regions outside of Scandinavia (Figure 4). These increases were being manifested in volume increases, lowering of equilibrium line altitudes (ELA) and advancing front positions. Prior to the 1970s, Scandinavian glaciers had been displaying a marked synchronous decline in their cumulative net mass balance, partly as a response to warming after the Little Ice Age (LIA), consistently with then contemporary global trends. However, since the 1970s the net mass balance of the maritime glaciers has been largely positive. Since the late 1980s, the rate of increase of cumulative mass balances of the maritime glaciers in Norway has been shown to accelerate, while the decreasing trend evident on the more continental glaciers ceases and becomes increasingly positive (Figure 5). 


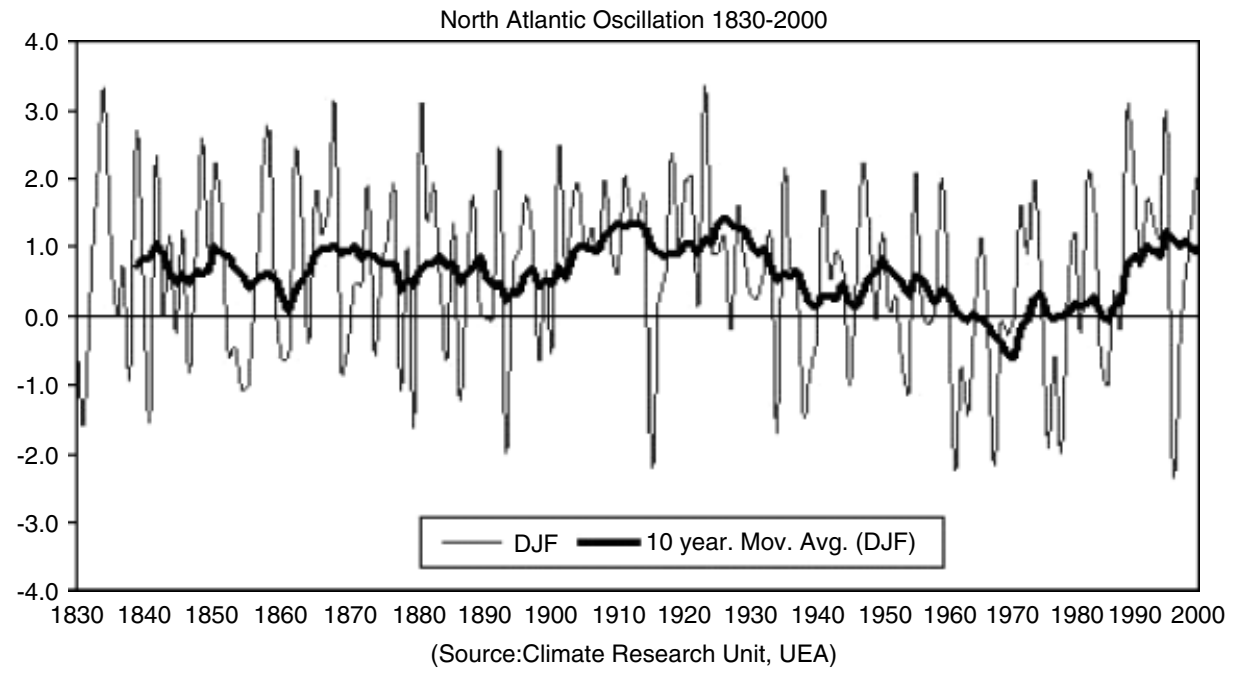

Figure 3. NAO Index 1830-2000

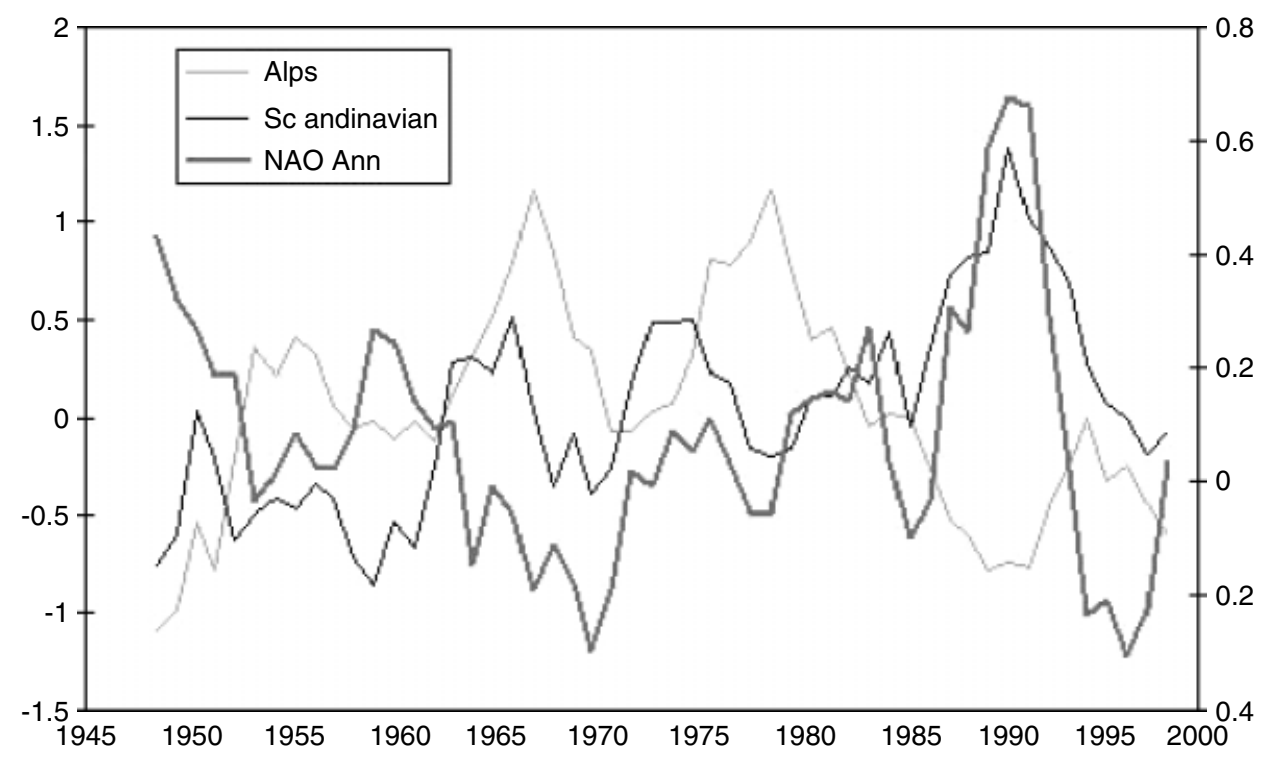

Figure 4. Five-year centred moving average of the standardised mean net balance of 11 Alpine glaciers (Alps) and 10 Scandinavian glaciers (Scandinavian) from 1948 to 2000. The annual NAO is also plotted (After Six et al., 2001)

\section{IDENTIFICATION OF CHANGE POINTS}

A cumulative sum of deviations (CUSUMs) analysis was initially performed on the seasonally averaged winter NAO to determine if any changes have occurred in the series that may help explain the accelerated rate of increase evident in the glacier mass balance series from Scandinavia. The method employed consists of calculating the cumulative sum of deviations or anomalies from the long-term mean for each series of interest (Sneyers, 1992). This method has been used in a number of previous studies to identify change points in climate series (Sneyers, 1992; Kiely, 1999; Hoppe and Kiely, 1999) and has also been used to detect inhomogeneities in climate series (Sneyers, 1992). However, it is sensitive to the effect of outliers. 


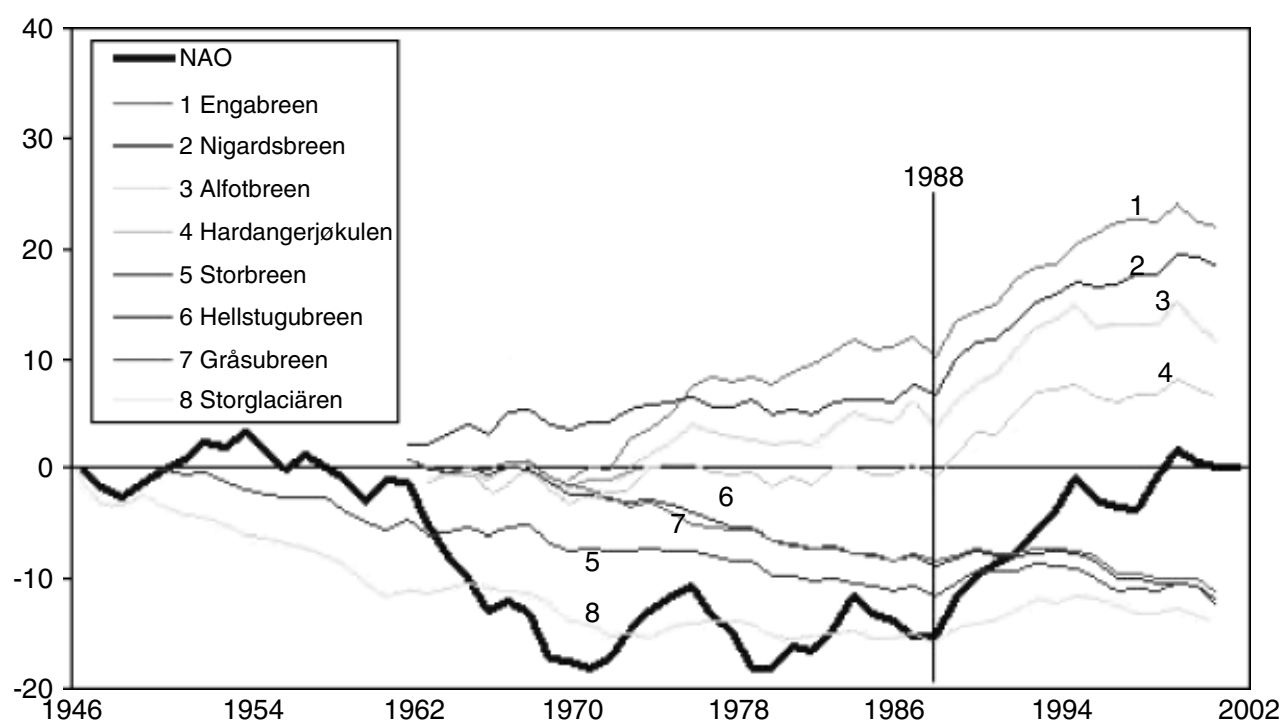

Figure 5. Cumulative net balance of selected Norwegian glaciers (including Storglaciären) and CUSUMs analysis of the winter NAO (glacier data from the Norwegian Water Resources and Energy Directorate; NAO data from Hurrell)

The Cusum is defined as follows:

$$
S_{i}=\sum_{i=n}^{i}\left(x_{i}-k\right)
$$

where $k$ is the average of the time series.

The hypothesis of no change in the mean value is rejected if max $\left|S_{i}\right|$ becomes too large (Kiely, 1999).

While the CUSUMs of the winter NAO identifies the existence of a local change point during the 1970s, in line with findings from previous studies, it also identifies two additional local change points as having occurred, during 1980 and 1988 (Figure 5). The identification of the occurrence of this later change point during 1988 is consistent with changes evident in the cumulative mass balance series from Scandinavia (Figure 5).

To determine the significance of this later change point and corroborate the findings of the CUSUMs analysis, the non-parametric Pettitt test (Pettitt, 1979) was also applied to the winter NAO series. The Pettitt test considers a time series as two samples represented by $x_{1} \ldots x_{t}$ and $x_{t+1} \ldots x_{\mathrm{T}}$. For continuous data the indices $V(t)$ and $U(t)$ can be calculated from the following formula

$$
U_{t, \mathrm{~T}}=U_{t-1, \mathrm{~T}}+V_{t, \mathrm{~T}}
$$

for $t=2, \ldots, \mathrm{T}$,

$$
V_{t, \mathrm{~T}}=\sum_{j=1}^{\mathrm{T}} \operatorname{sgn}\left(x_{t}-x_{j}\right)
$$

where,

$$
\begin{aligned}
& \operatorname{sgn}(x)=1, \text { for } x>0, \\
& \operatorname{sgn}(x)=0, \text { for } x=0, \\
& \operatorname{sgn}(x)=-1, \text { for } x<0 .
\end{aligned}
$$




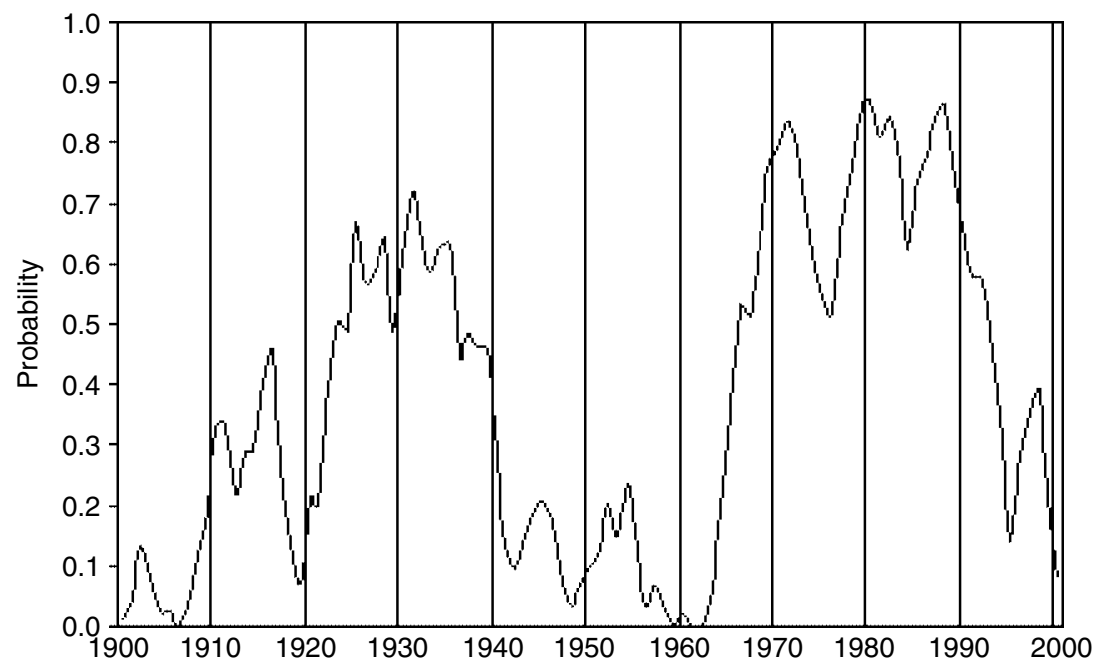

Figure 6. The probability of a change point in the winter NAO as determined from the Pettitt analysis (data: Hurrell)

The most significant change point is found where the value $\left|U_{t, \mathrm{~T}}\right|$ is maximum. The approximate significance probability, $p(t)$, of a change point can then be calculated from

$$
p(t)=1-\exp \left(\frac{-6 U_{t, \mathrm{~T}}^{2}}{\mathrm{~T}^{3}+\mathrm{T}^{2}}\right)
$$

(Pettitt, 1979)

Figure 6 displays the results from this analysis on the winter NAO for the period 1900-2000. Four local change points are identified as having occurred in the NAO index during the last century. A change point in 1931 marks a shift in the NAO from being predominantly positive up to this point to increasingly negative until the 1960s (Figure 3). A change point in the 1970s is associated with a trend towards more positive NAO values and has been the subject of much previous research (Bardossy and Caspary, 1990; Smith, 1995; Vincent and Vallon, 1997; Weber, 1997; Hoppe and Kiely, 1999; Kiely, 1999; Werner et al. 2000; Brunetti et al., 2001). The change point in 1980 is identified as having the highest probability (0.87) of the four change points identified, the timing of which is consistent with the findings of Hurrell (1995). A fourth change point in 1988 is identified as having the second highest probability of 0.86 . The results from the Pettitt analysis appear to substantiate the results of the CUSUMs analysis. While it does not have the highest probability, the effects of this later change point on glacier mass balance would appear to be more important than the previously identified change points (Figure 5).

The presence of change points was also examined for the seasonally averaged summer months of June to August. Figure 7 displays results from both a CUSUMs and Pettitt analysis on the EA-JP data for the period 1950-2000. Results from both these analyses indicate a number of local change points in the series. The year 1962 is highlighted in both series, although the Pettitt analysis attributes a low probability of 0.6 to this inflexion point in the data. The period 1980-1989 is identified by the Pettitt analysis as having the highest probability of a change point occurring, with probabilities greater than 0.96 for this period. The CUSUMs indicates the occurrence of three possible change points during this period - 1981, 1984 and 1989.

To further investigate the influence of the identified change points in both the NAO and EA-JP indices on the Scandinavian glacier mass balance series, correlations were derived on the basis of an 'increasing length of time series' (Hodge et al., 1998) of the mass balance and atmospheric data for both the winter accumulation and summer ablation period. This initially involved taking a minimum period of time, which amounted to approximately 18 years for the majority of the Norwegian glaciers $(\sim 1963-1980)$, 32 years for Storbreen 


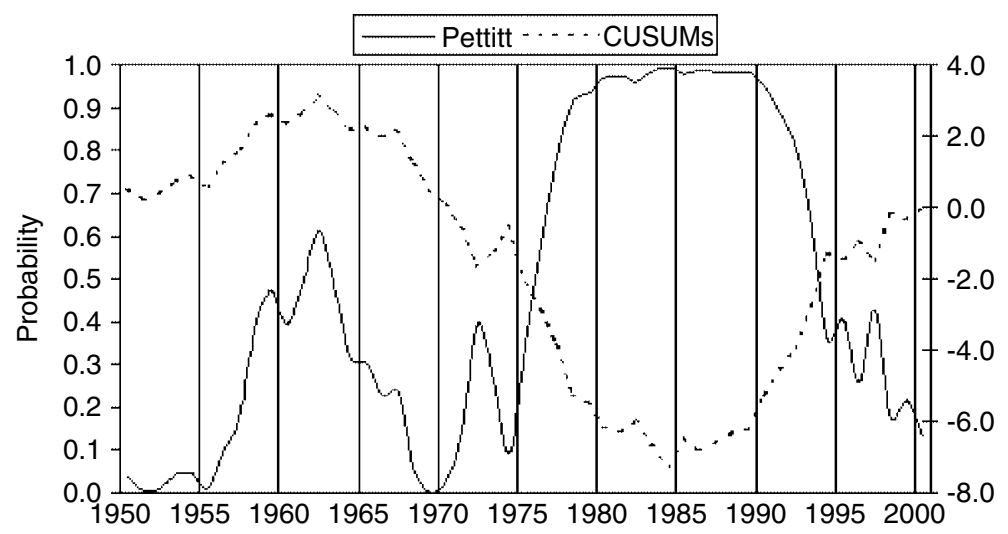

Figure 7. The probability of a change point in the EA-JP 1950-2000 as determined from a CUSUMs and Pettitt analysis (data from National Weather Service, climate prediction centre, NOAA)

(1949-1980) and 35 years for Storglaciären (1946-1980); deriving a correlation and then increasing the series by one year until all available years have been included in the analysis. The subsequent correlations, based on the incremented time series, can then be plotted over time to assess years in which obvious changes may have occurred (Figure 8 and Figure 9).

A change in the relationship between the NAO index and mass balance is suggested to have occurred after 1987. Five of the eight glaciers recorded their highest or second highest winter balance $(B \mathrm{w})$ on record as having occurred during either 1989 or 1990 , which coincides with a change in the relationship between climate and glaciers as suggested by Figure 5. The maritime glaciers of Ålfotbreen and Hardangerjøkulen display a more muted change in the Pearson's ' $r$ ' in comparison to the more continental glaciers of Gråsubreen and Hellstugubreen. However, continentality does not appear to be an overly influential factor on the change in the relationship as it is apparent at both maritime and continental glaciers in northern and southern Scandinavia.

Figure 9 displays the change in the relationship between the EA-JP and summer balance $(B \mathrm{~s})$ for the period up to 2000 that indicates that the change in climate-glacier relationships are consistent between both the accumulation and ablation seasons of 1988-1990. Five of the eight glaciers recorded net ablation values that were the highest or second highest on record during the ablation season of 1988 with the greatest losses being

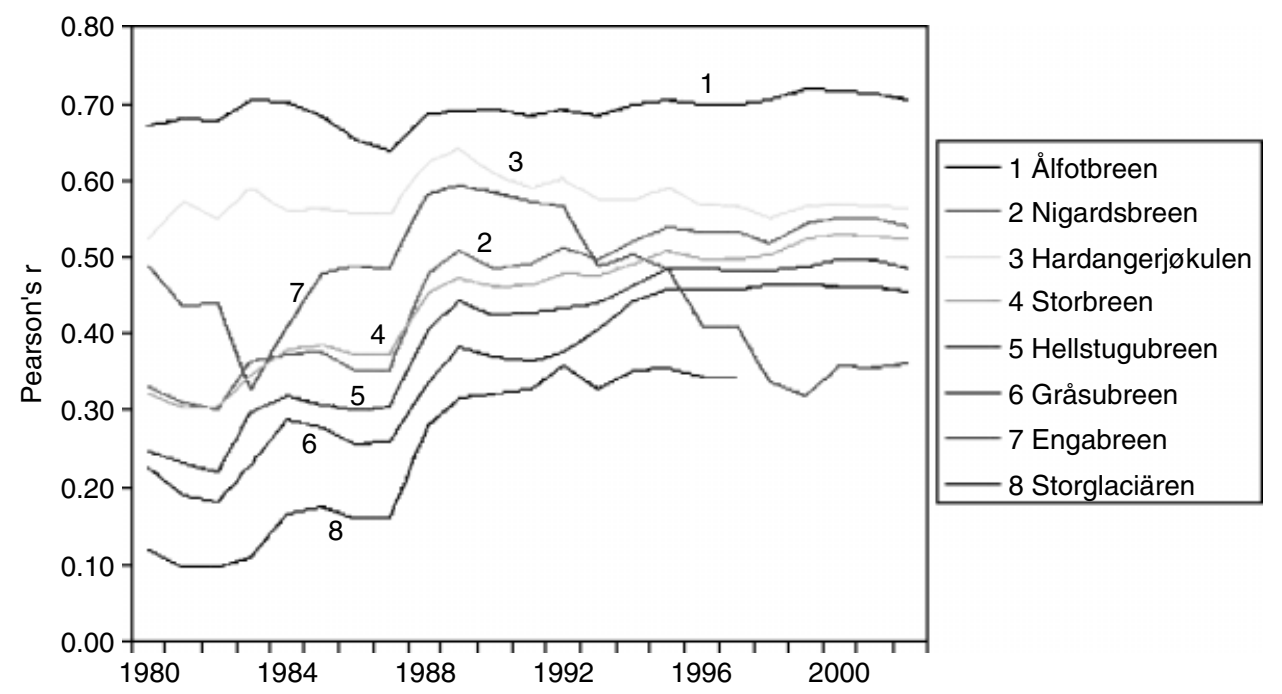

Figure 8. DJF NAO correlations (Pearson's $r$ ) with 'increasing length of time series' 1980-1999 and winter balance 


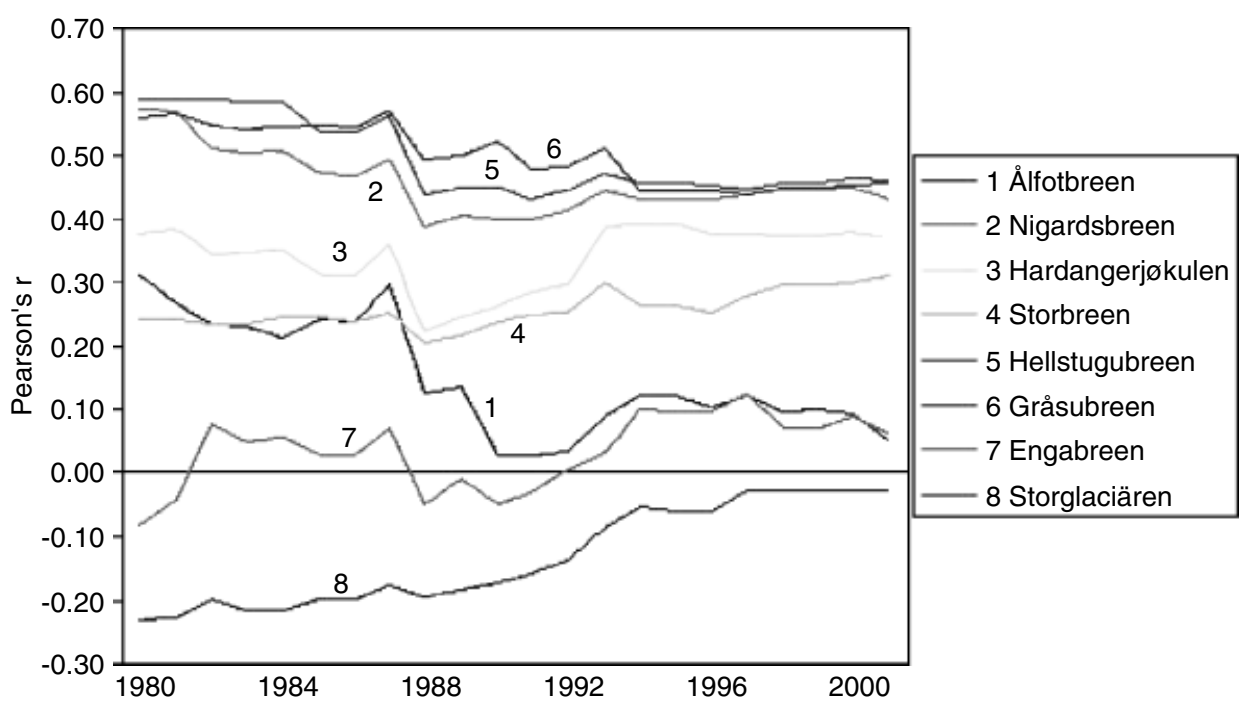

Figure 9. EA-JP correlations (Pearson's $r$ ) with 'increasing length of time series' 1980-1999 and summer balance

experienced on the maritime glaciers, while the more continental regime glaciers recorded their largest ablation values during 1997. However, the inclusion of more recent mass balance data that became available after this analysis was undertaken indicates that summer ablation values recorded in 2002 exceeded the previous records at six of the seven Norwegian glaciers.

To determine if the difference between the correlation coefficients, $r_{1}$ and $r_{2}$, between 1987 and 1989/1990 differ significantly from each other, the following test statistic was applied to two independent data series, where $r_{1}$ represents the correlation coefficient for both winter and summer for the period up to and including 1987 and $r_{2}$ represents the correlation coefficient for the period 1989-2003, representing the winter period, and 1990-2002 representing the summer period.

$$
\frac{z_{2}-z_{1}}{\sqrt{\frac{1}{n_{2}^{-1}}+\frac{1}{n_{1}^{-1}}}}
$$

Where $z$ is given by $z=1 / 2 \log _{\mathrm{e}}\left(\frac{1+r}{1-r}\right)$, a Fisher's Z-transformation that results in approximately normally distributed data with mean and standard deviation given by

$$
\begin{aligned}
& z=1 / 2 \log _{\mathrm{e}}\left(\frac{1+\rho}{1-\rho}\right) \\
& \frac{1}{\sqrt{n-1}} .
\end{aligned}
$$

Results, presented in Table II, demonstrate that changes in the correlation coefficient between the NAO and winter mass balance are significant at the 0.10 level for the glaciers of Nigardsbreen and Storbreen and at the 0.05 level for those at Hellstugubreen and Gråsubreen, while, for correlations between the EA-JP and $B \mathrm{~s}$, correlations are significant at the 0.05 level for just two glaciers, Storbreen and Storglaciären.

The timing of these step-like changes in the climate-glacier correlations is consistent with the change evident in the summed cumulative deviations of the NAO during 1988 (Figure 5) after which it strengthened for a number of years to levels not previously exceeded during the course of the twentieth century. 
Table II. Significance of the difference in the correlation coefficients for independent data based on the NAO and winter mass balance and the EA-JP and summer balance. $Z$ values greater than \pm 1.96 are significant at the 0.05 level and those greater than \pm 1.64 are significant at the 0.1 level

\begin{tabular}{lrc}
\hline Glacier & $\mathrm{NAO}_{\mathrm{DJF}} / B \mathrm{~W}-87 / 89-$ & $\mathrm{EA}_{\mathrm{JJA}} / B \mathrm{~s}-87 / 90-$ \\
& & \\
Ålfotbreen & 0.880 & 1.018 \\
Nigardsbreen & $\mathbf{1 . 6 5 8}$ & 1.055 \\
Hardangerjøkulen & -0.183 & 1.248 \\
Storbreen & $\mathbf{1 . 8 0 8}$ & $\mathbf{2 . 2 3 6}$ \\
Hellstugubreen & $\mathbf{2 . 3 1 1}$ & 1.022 \\
Gråsubreen & $\mathbf{2 . 0 4 3}$ & 0.859 \\
Engabreen & -0.857 & 0.037 \\
Storglaciären & 1.412 & $\mathbf{2 . 0 0 2}$ \\
\hline
\end{tabular}

\section{CHANGES IN PRECIPITATION AND TEMPERATURE}

The previous analysis identified the possible occurrence of a change point during the 1980s in the atmospheric variability of the North Atlantic. As temperature and precipitation are the two key variables that affect glacier mass balance, it is likely that any changes in these variables will be reflected in the glacier mass balance series. Temperature and precipitation series from three stations, Bergen, Troms $\emptyset$ and Sveg, were examined employing a methodology similar to that outlined in Section 4. Figures 10-13 display the results from the CUSUM analysis of both series.

Despite the lack of any obvious correspondence between the NAO and precipitation at Troms $\varnothing$ for most of the series, which may in part be attributable to the geographical location of Troms $\varnothing$ lying at the upper latitudinal boundary of influence of the NAO, after 1988 both appear to increase in relative unison (Figure 10). The correspondence between the NAO and precipitation is significantly better at Bergen over the entire record, but in particular after 1970. Again, 1988 is highlighted as a change point after which both the NAO and precipitation are shown to increase. Results of the analysis on winter precipitation from Sveg indicate a change point in 1990. A Pettitt analysis on the same data suggests that 1990 is the most significant change

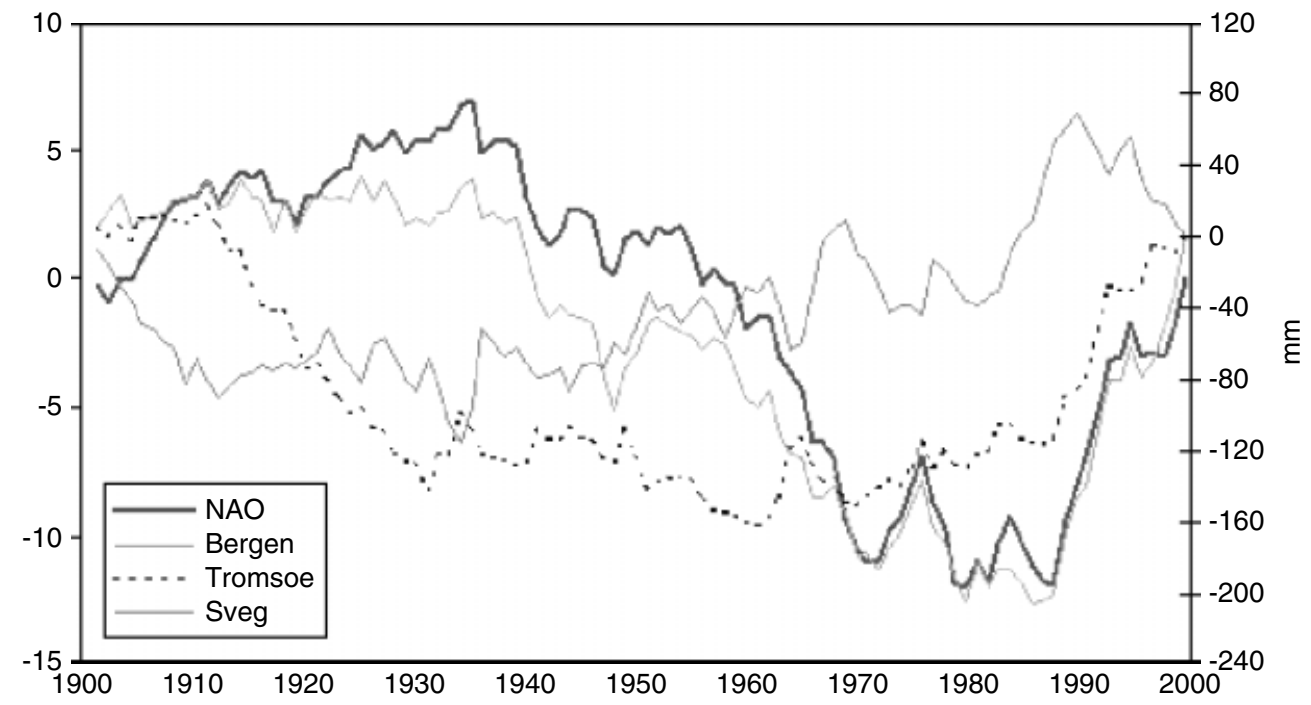

Figure 10. CUSUMs of NAO and winter precipitation for Troms $\varnothing$, Bergen and Sveg (Troms $\varnothing$ scaled by 3, Bergen scaled by 5) 


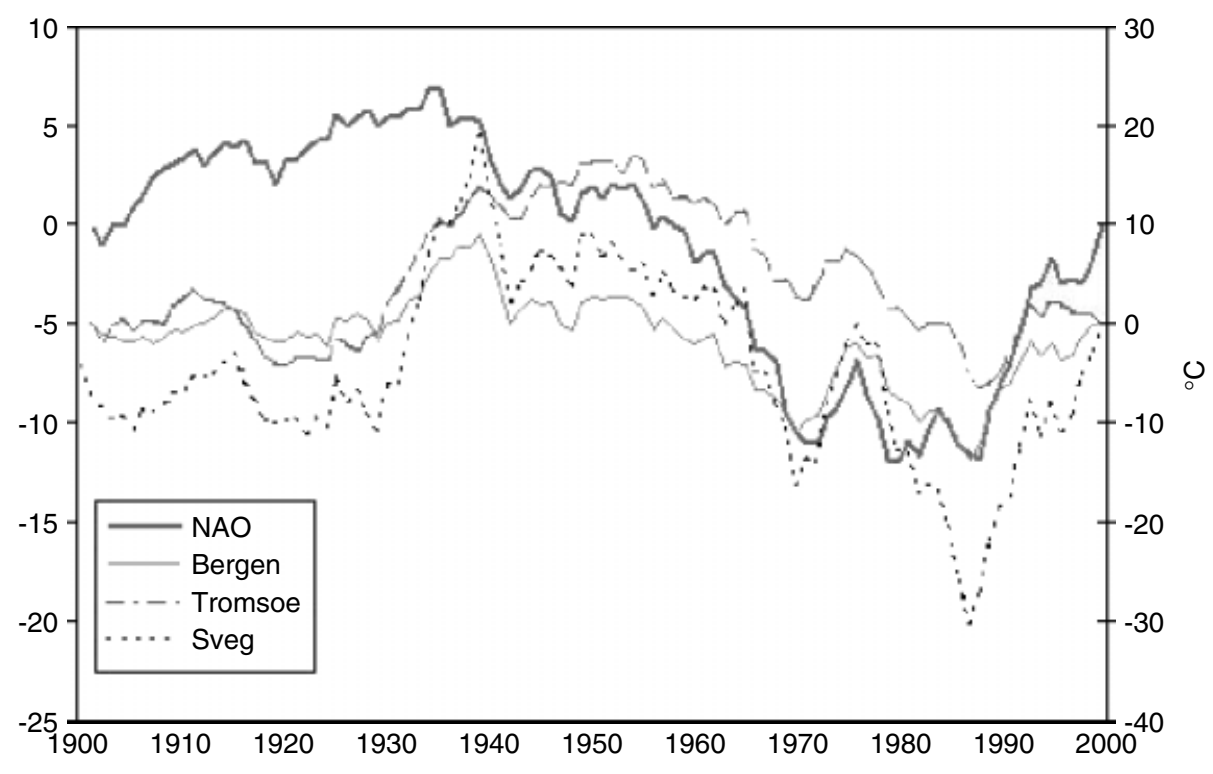

Figure 11. CUSUMs of NAO and winter temperatures for Tromsø, Bergen and Sveg

point in the series. This lag maybe attributed to its more continental location requiring a strengthened NAO in order for precipitation to penetrate further inland.

Winter temperatures show a high degree of correspondence with the NAO, in particular the temperature series from Bergen (Figure 11), consistent with the findings of Werner et al., 2000 in their analysis of climate change in the North Atlantic/European sector. They suggest that up to the beginning of the 1970s no correspondence was apparent between surface temperatures in the Northern Hemisphere and residence times of Grosswetterlagen types $\mathrm{W}$ and $\mathrm{CW}$. However, after this period both variables were found to increase at similar rates.

All temperature series indicate a change point in the early 1970s (1970-Bergen and Sveg, 1971-Troms $\varnothing$ ). The late 1980s also marks a second change point in the temperature series. However, 1987 is indicated as the most probable change point for both the Bergen and Sveg series, while 1988 is indicated as the most probable change point at Tromsø.

The CUSUMs analysis of the Scandinavian summer precipitation series displays a possible change point, particularly evident at Sveg, around the mid-1960s (Figure 12). Hanssen-Bauer and Førland (1998) in their analysis found reductions in summer precipitation between 1960 and 1975 that may explain the occurrence of this change point around the mid-1960s. However, these reductions were only found for stations in the southern half of Norway.

The Scandinavian summer temperature series also display a number of change points (Figure 13). The first change point around the end of the 1920s to the beginning of the 1930s marks an early century temperature maximum. From the 1930s to the 1960s, Scandinavian summer temperatures tend to decrease slightly, in response to mid-century cooling. The early 1970s marks a brief return to higher temperatures after which temperatures decline again until the 1980s.

Changes in the Scandinavian temperature and precipitation series, which are consistent with the largescale atmospheric changes, would seem to largely explain the mass balance changes evident on Scandinavian glaciers over the 1970-2000 period. The timing of these changes is reflected in the response time between the maritime and more continental regime glaciers. The winter precipitation series from Bergen indicates a change point in the early 1970s that marks a halt to the declining precipitation up to this point. After 1988, winter precipitation is shown to increase, resulting in increased rates of accumulation on maritime glaciers.

Precipitation at Troms $\varnothing$, which had been displaying an increasing trend from the 1960s, appears to increase after 1988. While precipitation at Sveg starts to increase after 1973, the 1980s marks a decade where 


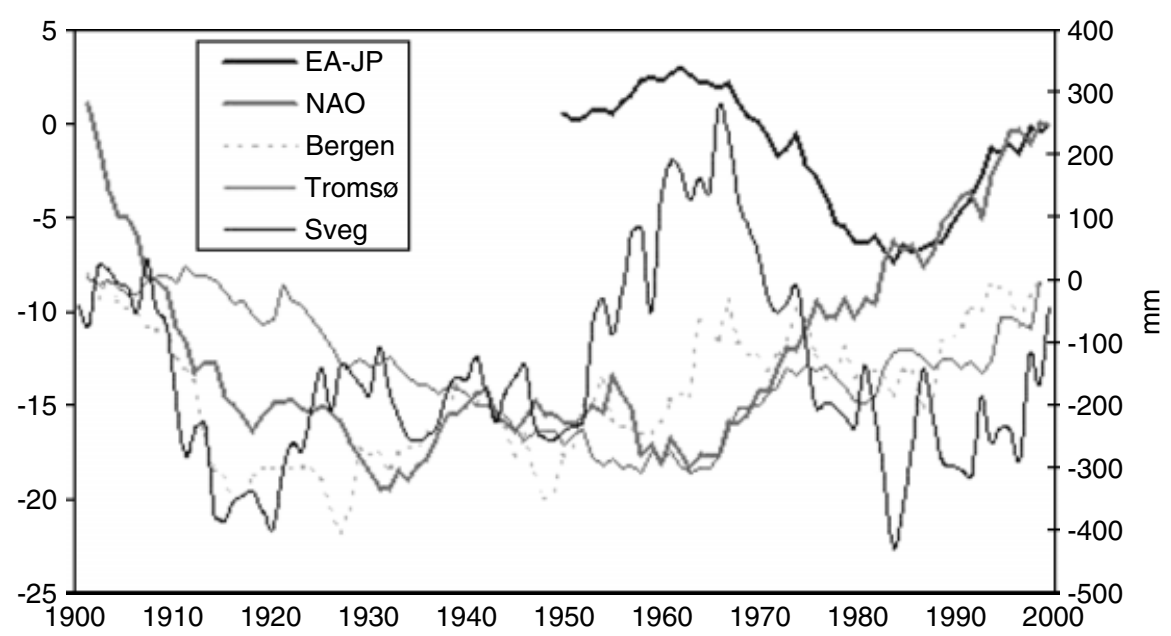

Figure 12. CUSUMs of NAO, EA-JP and summer precipitation for the Scandinavian stations

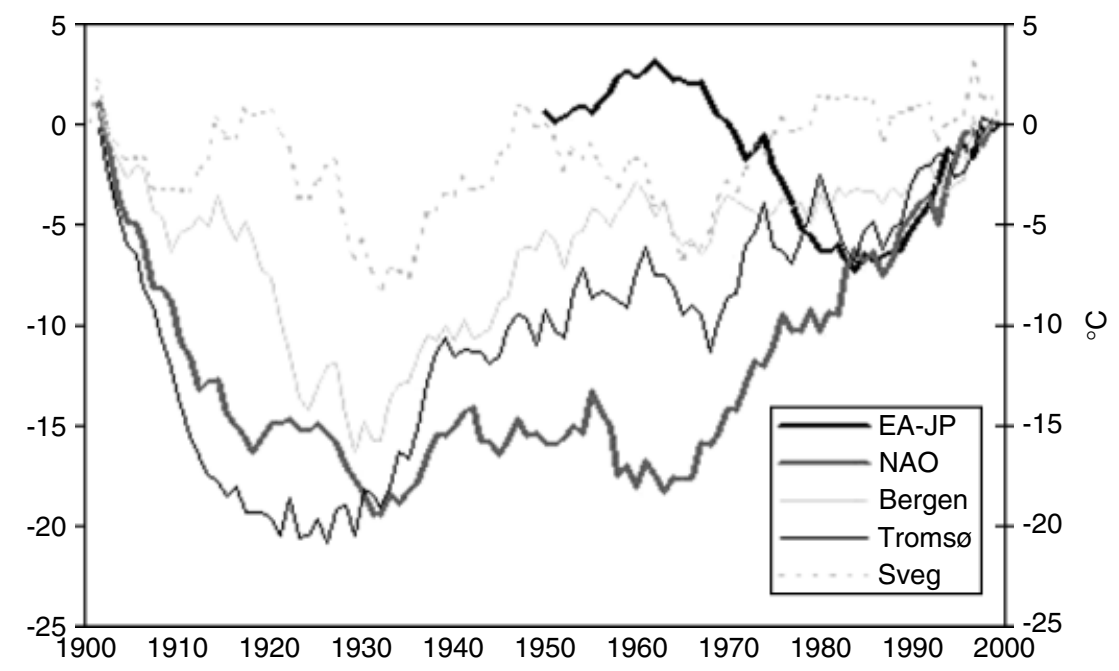

Figure 13. CUSUMs of NAO, EA-JP and summer temperatures for the Scandinavian stations

consecutive winter season precipitation amounts remain above average. The 1980s coincides with a period during which summer temperatures remained around their long-term mean value. Prior to this period, aboveaverage summer temperatures during the 1960s and 1970s would have resulted in increased losses during the ablation season, thereby minimising any gains from increased winter precipitation and resulting in the continued decline in the mass balance of the continental glaciers.

\section{CONCLUSIONS AND DISCUSSION}

In spite of the relatively small contribution of glaciers to the total terrestrial storage of ice, their sensitivity to changes in climate means that they are important contributors to decadal and longer timescale variations in sea level (Oerlemans and Fortuin, 1992; Dyurgerov and Meier, 1997). The current worldwide reduction apparent in the volume of glaciers is estimated to have already made a significant contribution to global sea level rise over the last 100 years. The rate of volume loss appears to have increased since the end of the 
1980s and predictions of global warming suggest that these trends are likely to continue. Between 1961 and 1976, glacier melt contribution to sea level was estimated to be $0.15 \mathrm{~mm} / \mathrm{yr}$ or $10 \%$ of total sea level rise (Dyurgerov, 2003). However, between 1988 and 1998, this contribution increased to $0.41 \mathrm{~mm} / \mathrm{yr}$ or $27 \%$ of total sea level rise (Dyurgerov, 2003).

Scandinavian glaciers and, in particular, Norwegian maritime glaciers have been shown to exhibit a current response to climate which is in contrast to that of glaciers on a global scale, with few minor exceptions. Positive cumulative net balances have resulted in glacier advances of a number of the maritime glaciers since the 1970s, halting the recession that was evident up to this period. The positive net balances being recorded on the maritime glaciers appear to be largely due to increases in winter precipitation, resulting in an accumulation surplus at the end of the balance year. These increases in precipitation, which Hanssen-Bauer and Førland (1998b) showed were statistically significant over southwestern regions of Norway from 1960 to 1997, are likely the results of increased zonal airflow (Førland et al., 1996) consistent with an increasing intensity of the NAO. The relationship between zonal flow and precipitation in southern Norway was also highlighted by Tveito (1996) who found that the correlation between zonal flow, as represented by a reduced index between Ona and Utsira-fyr, and precipitation, from Samnanger, was strongest in March, but was high for the whole year (Figure 14).

The present analysis has identified 1988-1990 as a period that warrants further investigation because of its potential climatic significance. Changes in the large-scale atmospheric variability of the North Atlantic, which were found to be consistent with changes in the temperature and precipitation series from Scandinavia, were also shown to be consistent with changes evident on maritime glaciers in Norway that have been demonstrating accelerated rates of increase in their cumulative net balance $(B n)$ since this period.

Hodge et al. (1998), in an analysis of climate variations and mass balance of three glaciers in western North America, also established that the year 1989 was a significant point after which there was a change in the relationship between climate and mass balance. Their research suggests that after this time, the glaciers under study not only started to display a coherent signal, but also demonstrated the highest rates of net mass loss over their entire records. They suggested a breakdown of the large-scale teleconnection between the Pacific Northwest and the tropical Pacific since 1989 to a degree that it was no longer statistically significant as the probable cause of the changes they found in mass balance (Hodge et al., 1998). They also suggest that this breakdown may prove to be more important than the regime shift that occurred in the Pacific during 1976-1977 (Hodge et al., 1998). Overland et al. (1998) in their analysis of the decadal variability of the Aleutian Low also identify 1989 as a change point year, with a shift from low to average values occurring

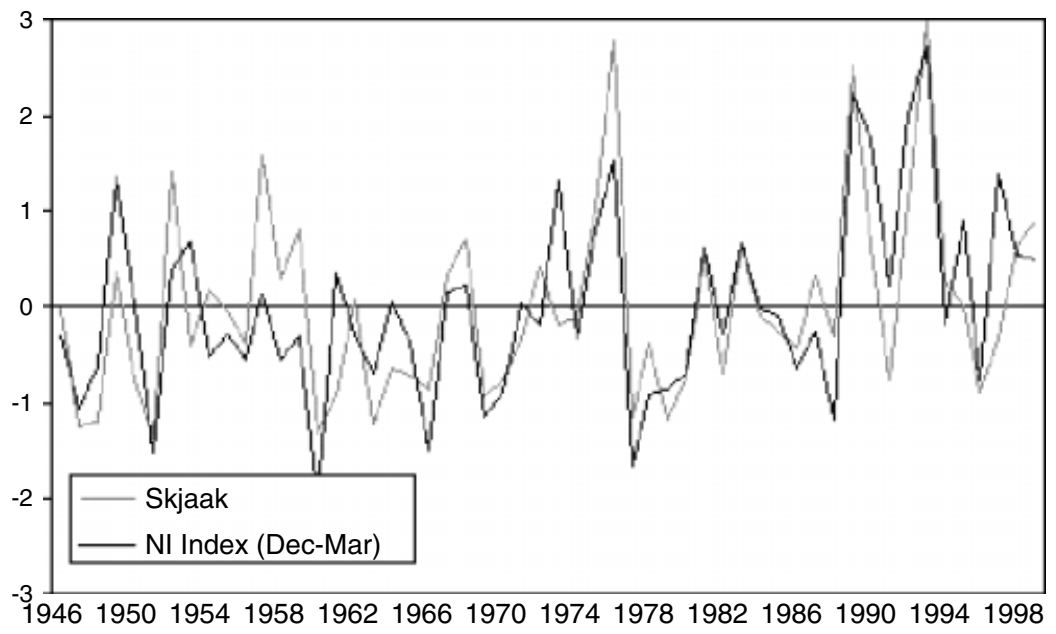

Figure 14. Standardised precipitation from Skjaak $\left(61^{\circ} 54^{\prime} \mathrm{N}, 8^{\circ} 10 \mathrm{E}\right)$ and a zonal index (NI index) constructed from standardised pressure from Ona $\left(62^{\circ} 52 \mathrm{~N}, 6^{\circ} 32 \mathrm{E}\right)$ and Utsira-fyr $\left(59^{\circ} 18 \mathrm{~N}, 4^{\circ} 53 \mathrm{E}\right)$. Both variables have been standardised relative to their mean over the period of measurement (Data from Frich et al., 1996; Tuomenvirta et al., 2001) 
in the Aleutian Low during winter. This change point identified in the Aleutian Low is preceded by a shift in the AO, which occurred in 1988 (Overland et al., 1998) with hemispherical-scale consequences.

The scale and effect of this shift would suggest that it is as significant as that detected in the early 1970s, which resulted in changes in the Arctic summer ice cover (Chapman and Walsh, 1993; Maslanik et al., 1996), convection in the Labrador Sea (Rhines, 1994), climate-glacier interactions in western North America (Hodge et al., 1998), a statistically significant change in glacier regime (Dyurgerov, 2003) and a decline in cod recruitment in the Atlantic since the mid 1980s were linked to rising temperatures (Beaugrand et al., 2003). Also during this period, Mysak and Power (1991) found large positive sea ice anomalies occurring in the Greenland Sea, which had been preceded by above-average run-off from North America into the western Arctic. They suggested that this sequence is part of a self-sustained climatic oscillation in the Arctic, occurring with a period of approximately 15-20 years, and hence might be a component of interdecadal climate variability. However, observations linking atmospheric circulation and precipitation were scarce, so no significant conclusions could be made with regard to the proposed climate oscillation (Holland et al., 1995). Despite this, sea ice does appear to be an important component in interdecadal climate variability (Holland et al., 1995). However, it maybe that the change point identified in the Scandinavian glacier mass balance records during the late 1980s was part of a larger-scale set of changes indicative of global atmospheric variability changes that drive changes in climate.

\section{ACKNOWLEDGEMENTS}

The authors gratefully acknowledge the comments of the two external reviewers. The authors would also like to thank Dennis Pringle, Jim Walsh and Dennis Conniffe (NUI Maynooth) for their input on some of the statistical issues that arose during the course of preparing this paper.

\section{REFERENCES}

Bardossy A, Caspary HJ. 1990. Detection of climate change in Europe by analyzing European Atmospheric Circulation Patterns from 1881 to 1989. Theoretical and Applied Climatology 42: 155-167.

Beaugrand G, Brander KM, Lindley JA, Souissi S, Reid PC. 2003. Plankton effect on cod recruitment in the North Sea. Nature 426: $661-664$.

Benn DI, Evans DJA. 1998. Glaciers and Glaciation. Arnold: London.

Brunetti M, Colacino M, Maugeri M, Nanni T. 2001. Trends in the daily intensity of precipitation in Italy from 1951 to 1996. International Journal of Climatology 21: 299-316.

Chapman WL, Walsh JE. 1993. Recent variations of sea ice and air temperature in high latitudes. Bulletin of the American Meteorological Society 74(1): 33-47.

Chen D, Hellström C. 1999. The influence of the North Atlantic Oscillation on the regional temperature variability in Sweden: spatial and temporal variations. Tellus 51A: 505-516.

Dyurgerov M. 2002. Glacier Mass Balance and Regime: Data of Measurements and Analysis, Occasional Paper No. 55. Institute of Arctic and Alpine Research, University of Colorado.

Dyurgerov M. 2003. Mountain and subpolar glaciers show an increase in sensitivity to climate warming and intensification of the water cycle. Journal of Hydrology 282: 164-176.

Dyurgerov MB, Meier MF. 1997. Year to year fluctuations of global mass balance of small glaciers and their contribution to sea-level changes. Arctic and Alpine Research 29(4): 392-402.

Dyurgerov MB, Meier MF. 1999. Analysis of winter and summer glacier mass balances. Geografiska Annaler 81A: 4.

Førland EJ, van Engelen A, Hanssen-Bauer I, Heino R, Ashcroft J, Dahlström B, Demarée G, Frich P, Jónsson T, Mietus M, MüllerWestermeier G, Pálsdottir T, Toumenvirta H, Vdein H. 1996. Changes in normal precipitation in the North Atlantic region. Klima Report No. 7/96. Oslo DNMI.

Frich P (Co-ordinator), Alexandersson H, Ashcroft J, Dahlström B, Demarée G, Drebs A, van Engelen A, Førland EJ, Hanssen-Bauer I, Heino R, Jónsson T, Jonasson K, Keegan L, Nordli PØ, Schmith T, Steffensen T, Tuomenvirta H, Tveito OE. 1996. North Atlantic Climatological Dataset (NACD version 1)-final report. DMI Scientific Report 96-1, Copenhagen DNMI publishers 47.

Hanssen-Bauer I, Førland EJ. 1998. Annual and seasonal precipitation variations in Norway 1896-1997. Klima Report No. 27/98. Oslo DNMI.

Hodge SM, Trabant DC, Krimmel RM, Heinrichs TA, March RS, Josberger EG. 1998. Climate variations and changes in mass of three glaciers in western North America. Journal of Climate 11: 2161-2179.

Holland WR, Capotondi A, Holland MM. 1995. Advances in ocean modeling for climate change research. Reviews of Geophysics 33: $1411-1424$.

Hoppe H, Kiely G. 1999. Precipitation over Ireland-Observed change since 1940. Physics and Chemistry of the Earth Part B 24(1-2): $91-96$.

Hurrell JW. 1995. Decadal trends in the North Atlantic Oscillation, regional temperatures and precipitation. Science 269: 676-679. 
Hurrell JW, Dickson RR. 2001. Climate variability over the North Atlantic. Murine Ecosystems and Climate Variation - The North Atlantic - A co-operative perspective, Hurrell JW, Belgrano A (eds). Oxford University Press: 1-30.

Kiely G. 1999. Climate change in Ireland from precipitation and streamflow observations. Advances in Water Resources 23: 141-151. Marshall J, Kushnir Y. 1997. A 'white paper' on Atlantic Climate Variability. April 1997. http://geoid.mit.edu/accp/avehtml.html.

Marshall J, Kushnir Y, Battisti D, Chang P, Czaja A, Dickson R, Hurrell J, McCartney M, Saravanan R, Visbeck M. 2001. North Atlantic climate variability: phenomena, impacts and mechanisms. International Journal of Climatology 21: 1863-1898.

Maslanik JA, Serreze MC, Barry RG. 1996. Recent decreases in Arctic summer ice cover and linkages to atmospheric circulation anomalies. Geophysical Research Letters 23(13): 1677-1680.

McCabe GJ, Fountain AG. 1995. Relations between atmospheric circulation and mass balance of South Cascade Glacier, Washington, U.S.A. Arctic and Alpine Research 27(3): 226-233.

Mysak LA, Power SB. 1991. Greenland Sea ice and salinity anomalies and interdecadal climate variability. Climatological Bulletin 25: 81-91.

Nesje A, Dahl SO. 2000. Are the North Atlantic and Arctic Oscillation reflected in Scandinavian glacier mass balance records? Pages Newsletter 8(2): 15.

Nesje A, Lie Ø, Dahl SO. 2000. Is the North Atlantic Oscillation reflected in Scandinavian glacier mass balance records? Journal of Quaternary Science 15(6): 587-601.

Oerlemans J. 2005. Extracting a Climate Signal from 169 Glacier Records, www.sciencexpress.org/03 March 2005/Page 4/10.1126/science. 1107046.

Oerlemans J, Fortuin JPF. 1992. Sensitivity of glaciers and small ice caps to greenhouse warming. Science 258: 115-117.

Overland JE, Miletta Adams J, Bond NA. 1998. Decadal variability of the Aleutian Low and its relation to high-latitude circulation. Journal of Climate 12: 1542-1548.

Pettitt AN. 1979. A non-parametric approach to the change-point problem. Applied Statistics 28(2): 126-135.

Pohjola VA, Rodgers JC. 1997a. Coupling between the atmospheric circulation and extremes of the mass balance of Storglaciären, northern Scandinavia. Annals of Glaciology 24: 229-233.

Pohjola VA, Rodgers JC. 1997b. Atmospheric circulation and variations in Scandinavian glacier mass balance. Quaternary Research 47: $29-36$.

Rhines PB. 1994. Climate change in the Labrador Sea, its convection and circulation. In Proceedings from the Principal Investigators Meetings, Atlantic Climate Change Program (ACCP), Princeton, 9th-11th May, 1994.

Rogers JC. 1990. Patterns of low-frequency monthly sea level pressure variability (1899-1986) and associated wave cyclone frequencies. Journal of Climate 3: 1364-1379.

Six D, Reynaud L, Letréguilly A. 2001. Bilans de masse des glaciers alpins et scandinaves, leur relations avec l'oscillation de climat de l'Atlantique nord. Earth and Planetary Sciences 333: 693-698.

Smith K. 1995. Precipitation over Scotland, 1757-1992: some aspects of temporal variability. International Journal of Climatology 15: $543-556$.

Sneyers R. 1992. On the use of statistical analysis for the objective determination of climate change. Meteorologische Zeitschrift N.F. 1: $247-256$.

Tuomenvirta H, Drebs A, Førland E, Tveito OE, Alexandersson H, Laursen EV, Jónsson T. 2001. Nordklim data set 1.0 description and illustrations. DNMI Report 08/01 Klima. Oslo DNMI.

Tveito OE. 1996. Trends and variability in North Atlantic pressure series. DMNI-Report No. 27/96 Klima. Norwegian Meteorological Institute: Oslo.

Vincent C, Vallon M. 1997. Meteorological controls on glacier mass balance: empirical relations suggested by measurements on glacier de Sarennes, France. Journal of Glaciology 43(143): 131-137.

Washington R, Hodson A, Isaksson E, MacDonald O. 2000. Northern hemisphere teleconnection indices and the mass balance of Svalbard glaciers. International Journal of Climatology 20: 473-487.

Weber G-R. 1997. Spatial and temporal variations of $300 \mathrm{hPa}$ temperatures in the Northern Hemisphere between 1966 and 1993. International Journal of Climatology 17: 171-185.

Werner PC, Gerstengarbe F-W, Fraedrich K, Oesterle H. 2000. Recent climate change in the North Atlantic/European sector. International Journal of Climatology 20: 463-471. 